\title{
Dorothy Hale
}

\section{Introduction to Social Formalism (1998)}

\begin{abstract}
English Summary
In this introductory chapter to her book Social Formalism: The Novel in Theory from Henry James to the Present (1998), Dorothy Hale is engaging a double polemic against the dominating tradition within cultural studies and argues that not only does this tradition, which claims to have more interest in the 'world' than in the 'work', base its studies in classical literary works; it has also lost sight of the relevant theoretical approaches. To Hale, a reactualization of 'novel theory' is therefore emergent, and it is the aim of her study to show that the critique that has been raised against formalistic-oriented novel theory for not having any other interest in the novel than the description of its 'literariness' is wrong. Literary theorists like Henry James, Percy Lubbock, Wayne Booth, Gérard Genette and Michail Bachtin have shared the conviction that the novel, through its formal aspects, embodies the author's vision of both social identity and social reality - no matter whether this is formulated as Lubbock's 'vision', Genette's 'voice' or Bachtin's 'dialogicity'. In this respect, these theorists are not as far from the sociocultural approaches of Eve Kosofsky Sedgwick, Barbara Johnson and Henry Louis Gates as is claimed. They are connected insofar as they share a social formalistic interest, i.e. they consider the formal aspects of the text as an expression for and a result of a specific and historically variable social formation.

From Social Formalism: The Novel in Theory from Henry James to the Present by Dorothy Hale, (c) 1998 by the Board of Trustees of the Leland Stanford Jr. University, all rights reserved. Translated by arrangement with Stanford University Press, www.sup.org.
\end{abstract}

\section{Dorothy Hale}

Professor ved English Department, University of California, Berkeley. Blandt Dorothy Hales seneste udgivelser er The Novel: An Anthology of Criticism and Theory, 1900-2000, Malden, MA $2006 \mathrm{og}$ "Fiction as Restriction: Self-Binding in New Ethical Theories of the Novel in Narrative 15:2 (2007), pp.187-206. Udgav i 1998 Social Formalism. The Novel in Theory from Henry James to the Present, som blev tildelt The Barbara Perkins and George Perkins Award af The Society for the Study of Narrative Literature i 2000. Den her oversatte tekst er introduktionskapitlet fra denne bog.

K\&K 104 (2007), 16-33 


\section{Dorothy Hale}

\section{Introduktion til Social Formalism (1998)}

Hvad var romanteori? Romanteori, det vil sige forsøget på at formulere det særegne ved romanen som litterær form, synes enten at blive opgivet eller ignoreret, $i$ takt med at litteraterne udvikler sig til at være kulturanalytikere, idet de vender opmærksomheden bort fra teksten mod den sociale kontekst, fra poetik mod ideologi. I begyndelsen af århundredet, da litteraterne tilskrev romanen en enestående teknisk kompleksitet, vandt romanen ny anseelse som kunstform. Nu bliver romanens værdi defineret ud fra dens ideologiske typificitet. Eftersom romandiskussioner drejer sig om spørgsmålet om dens kulturelle funktion, synes litteraterne kun at have ringe interesse $\mathrm{i}$ eller behov for, hvad der i begyndelsen af århundredet af mange blev anset for at være formålet med litterær analyse i almindelighed og formålet med romanteori i særdeleshed: isoleringen og beskrivelsen af de generiske træk, som ikke kun adskilte ét litterært objekt fra et andet, men også definerede det litterære som en logisk kategori. ${ }^{1}$ Formelle og generiske beskrivelser af romanen er i stigende grad blevet underlagt det næsten hermetisk lukkede narratologiske studieområde, som fra sit strukturalistiske afsæt lidenskabeligt har påtaget sig det i stigende grad forfinede terminologi-erhverv. Det er muligt, at narratologer debatterer de relative fortjenester i begreber som fx »fokalisering « og »filter « med hinanden; at de arbejder på at kunne karakterisere »narrativ tid og dens anerkendte tempi«; at kunne skelne mellem »senere, tidligere, samtidige og indskudte « narrative strukturer og på at opdage en mangfoldighed af »implicitte « narratologiske agenter, men kulturanalytikere synes at finde det gammeldags ordforråd, som plot, karakter, synsvinkel og direkte fremstilling, helt tilstrækkeligt til deres fortolkningsmæssige formål. ${ }^{2}$ Det er snarere narratologerne, som mener, at deres egen praksis er underteoretiseret. Kulturanalytikere savner ikke en teknisk terminologi, der præcist angiver romanens indre virkemåder, men narratologer har set sig nødsaget til at udvide deres studie af romanen for at beskrive det ideologiske arbejde, som genren udfører. ${ }^{3}$

Men selvom romanteorien begyndte at visne midt i dens blomstring, 
har romanstudierne aldrig været mere solide. At underprivilegere den litterære genstand som sådan har udelukkende øget bestanden af romaner i almindelighed ved ikke kun at gøre den 'litterære' roman, men enhver roman overhovedet, til genstand for seriøs analytisk opmærksomhed. Romanen synes at hævne sig på akademiet. I to århundreder blev romanen skønnet uværdig til at have sin egen poetik. $\mathrm{Nu}$, hvor sådan en poetik synes at være død, bliver romanen ved med at danse på dens grav. Denne nye triumf for romanen er selvfølgelig et paradoksalt fænomen. Romanen er blevet en foretrukken genstand for litterært studie, netop fordi den bliver behandlet som den genre, der er »mindst « litterær - den udmærker sig (hvis det er termen) ved sin almindelighed, sin popularitet, ved at være afledt af andre kulturelle diskurser. ${ }^{4}$ Netop de træk, som i to århundreder gav romanen et dårligt æstetisk ry, anses nu for at være kilden til dens kulturelle magt.

En 'ny' investering i romanen som den mest sociale af litterære former var imidlertid lige så central for romanteorien som for de kulturstudier, som tilsyneladende har erstattet den - hvilket antyder, at meldingerne om romanteoriens død må have været voldsomt overdrevne. Det vil faktisk være en afgørende påstand i Social Formalism, at kulturstudier er blevet markant påvirket af en teoretisk tradition omkring romanen, hvis rødder kan henføres til Henry James' formalistiske kritik. Ved at vise, at kulturstudier er mere afhængige af romanteorien, end man er sig bevidst, vil Social Formalism også forsøge at bevise, at romanteori ikke just er den formalisme, som vi har anset den for at være.

Måske lader den generelle forbindelse mellem formalistiske og kulturelle tilgange til romanen sig bedst forstå, hvis vi overvejer de teoretiske vanskeligheder, som kulturanalytikere har mødt i og med, at de har skullet retfærdiggøre deres studier af romanen. Mange af disse litterater har postuleret en særlig sammenhæng mellem den litterære forms ideologi, og hvad vi kunne kalde ideologiens litterære form. Eve Kosofsky Sedgwicks Between Men: English Literature and Male Homosocial Desire (1995) er et yderst indflydelsesrigt eksempel. Sedgwick spørger direkte (og svarer så indirekte på), hvorfor hendes studie af »det homo-sociale kontinuum « skulle være et »litterert spørgsmål . $^{5}$

Hendes forklaring begynder med en diskussion af en amerikansk bestseller-roman, Gone with the Wind. I og med at Sedgwick kalder Gone with the Wind for en »ideologisk salgssucces for hvid, småborgerlig feminisme", antyder hun, at romaner er værd at ofre opmærksomhed på, fordi de er populære og derfor ideologisk indflydelsesrige kulturelle former ( $B M$, p. 8). Men i denne bog om den engelske litterære tradition fra Shakespeare til Dickens er det bestemt ikke amerikanske og knapt britiske 
sociokulturelle detaljer, der interesserer Sedgwick. Hendes emne er heller ikke salgssucceser. Hvad, der ifølge Sedgwick til syvende og sidst gør Gone with the Wind til en salgssucces, har mindre at gøre med dens salgstal end med dens formelle kraft. I hendes forklaring må portrættet af det sociale i Gone with the Wind opfattes som sa helt igennem karakteristisk for det samfund, den blev skrevet $i$, at romanen ender med at udgøre en selvtilstrækkelig repræsentation af den ideologi, som den afspejler: den er et »ideologisk mikrokosmos « (BM p. 10). Derfor føler Sedgwick sig ikke tvunget til at gå udenfor Gone with the Wind for fx at studere den kulturelle »voldtægtsdiskurs ", som romanen eksemplificerer. ${ }^{6}$ Hvis romanen, i Sedgwicks læsning, ikke længere er en afsondret formalistisk verden, beholder den ikke desto mindre meget af den repræsentationsautonomi, den havde under det gamle nykritiske regime, som Sedgwick har hjulpet med at fortrænge. Den kulturanalytiker, der har helliget sig at fratage romanen sit privilegium af æstetiske grunde, finder sig selv i færd med at genindføre romanens formmæssige privilegium på grund af dens sociale repræsentativitet. ${ }^{7}$ Jeg vil hævde, at en sådan overbevisning om, at romanen formmæssigt både kan indkapsle og fiksere en social verden, er den stærkeste forbindelse mellem det nye kulturstudie af romanen og den formalistiske romanteoretiske tradition, som man så stærkt ønsker at afvige fra.

Kun ved at undersøge denne forbindelse, som jeg kalder 'socialformalisme', er det muligt at forklare, hvordan andre underordnede romanteoretiske emner har formået at opretholde en dominerende position $\mathrm{i}$ de vokabularer, som anvendes af den nye ideologiske lærdom. Et af disse emner er 'synsvinkel'. I 1921 erklærer den jamesiske elev og romanteoretiker Percy Lubbock, at »hele det indviklede spørgsmål om metode i fiktionsværket ser jeg som styret af spørgsmålet om synsvinkel«. I 1985 præsenterer kulturhistorikeren Jane Tompkins synsvinkel som nøglen til hele det indviklede spørgsmål om ideologi:

»Fordi jeg ønsker at forstå, hvad der gav disse romaner styrke for deres første læsere, syntes det vigtigt at genskabe, så realistisk som muligt, konteksten, fra hvilken romanerne udsprang og de specifikke problemer, som de omhandlede. Jeg har derfor ikke kritiseret de sociale og politiske holdninger, som motiverede disse forfattere, men jeg har i stedet forsøgt at bebo det standpunkt, hvorfra deres politik gav mening og at gøre det tilgængeligt for et moderne publikum. $\ll^{8}$

Hvorfor antager Tompkins, at den bedste måde at forstå romaner fra fortiden på, er at bebo deres originale publikums synsvinkel? Som hun selv 
pointerer, giver denne videnskabelige indstilling afkald på enhver kritik af tidligere »sociale og politiske holdninger «. Ydermere ville den imaginære beboelse af fremmedartede og anakronistiske synspunkter synes særdeles vanskelig for en litterat, der fastholder, at hun selv er fast forankret i de kulturelle interesser, der udgør hendes eget synspunkt.9 Som Tompkins formulerer det, »enhver rekonstruktion af 'kontekst' er lige så bestemt af fortolkerens holdninger og værdier, som udlægningen af litterære værker er det; min læsning af det historiske materiale vokser, ligesom de tekstanalyser jeg laver, direkte ud af de omstændigheder, interesser og mål, der har dannet mig som litterat «. ${ }^{10} \mathrm{Og}$ alligevel insisterer Tompkins på, at en litterat, til en vis grad, for at fange romaners styrke »for deres første læsere «, må blive de læsere. ${ }^{11}$ Antagelsen om, at det at forstå en roman er at bebo en synsvinkel, virker som en arv fra romanteorien, som Tompkins ukritisk har overtaget. En anden, lignende arv, jeg håber på at kunne vise, er det logiske såvel som etiske bånd, som hun vender sig mod i sit forsøg på at mægle mellem den synsvinkel, som hun sympatiserer med og den synsvinkel, hvorfra hun sympatiserer.

Generelt set er problemet, som socialformalister bestræber sig på at gøre noget ved, hvordan objektiv fortolkning kan blive gennemført i en verden, hvor betydning nødvendigvis er subjektiv, afhængig af ens synsvinkel. Socialformalisternes overbevisning om, at der ikke er nogen mening hinsides subjektiviteten er så stærk, at subjektivitet i sig selv, i denne tradition, bliver den eneste mulige betydning. Men fordi socialformalister er lige så forpligtigede på en moralsk overbevisning om det iboende gode ved anderledeshed, at mennesker er mest imødekommende, når de lærer sympatiske personer, som er væsentligt anderledes end dem selv at kende, så har de interesse i at mildne den radikale relativisme, som kendetegner deres ontologiske position. Derfor tilskriver de visse repræsentationelle former magten til at løse og begrænse subjektiv mægling gennem konkretisering af identitet. De forestiller sig i særdeleshed, at romanens form helt præcist kan eksemplificere såvel romanens forfatters identitet som det subjekts identitet, som forfatteren søger at representere. Hvis denne definition på det sociale virker så minimalistisk, at den knap nok retfærdiggør termen, så er det præcis min pointe. Det, som er bemærkelsesværdigt ved den tradition, som jeg forfølger, er, at denne subjektivistiske litterære formalistiske fremstilling af identitet, repræsentation og fortolkning bliver det, som understøtter en af de mest indflydelsesrige 'sociale' teorier i det tyvende århundrede.

Selvom det er ganske rigtigt, at begrebet om det sociale i den tradition, jeg her analyser, er hårdt kompromitteret af dets teoretikeres formalisme, er der ikke min hensigt at påstå, at hver litteraturkritisk eller litteratur- 
teoretisk anråbelse af det sociale nødvendigvis er formalistisk. ${ }^{12}$ Sammenblandingen af socialhistoriske og formalistiske hensigter, som jeg her har beskrevet, er ikke logisk uundgåelig. Der er i sagens natur ikke noget socialformalistisk over de spørgsmål om roman og samfund, som er blevet stillet af så betydningsfulde litteraturhistorikere som Nancy Armstrong, Nina Baym, Cathy Davidson, Richard Brodhead, Philip Fisher, Catherine Gallagher, Sandra Gilbert og Susan Gubar og D.A. Miller - spørgsmål om fx, årsagen til romanens fremgang, hvad der forårsagede, at denne særlige kulturelle diskurs opstod, og hvilket ideologisk arbejde romanen ydede i bestemte perioder.

Ikke desto mindre er det overraskende at se, hvor ofte de historisk determinerede svar, som disse litterater bringer for dagen, ikke kun antager samme form som romanteoretikerens forestilling om romanen, men på bemærkelsesværdig vis spejler den. Uden hensyntagen til periode eller national oprindelse viser romanens primære ideologiske opgave sig at være at fremme sympati. I sin studie af amerikanske romaner fra før Den Amerikanske Borgerkrig argumenterer Nina Baym for eksempel for, at romanagtig sympati, fremmet gennem manipulationen med karakter og synsvinkel, fungerede som en revolutionær, social styrke, der udfordrede kulturelle autoriteter. ${ }^{13}$ Richard Brodhead hævder på den anden side, at den romaninspirerede sympati bidrog til opfindelsen af »disciplinær intimitet «, konsolideringen af »det følelsesmæssige bånd mellem den myndige skikkelse og dens tiltale « som foranledigede tilbagegangen i legemlig afstraffelse og blev det nittende århundredes amerikanske middelklasses »selvidentificerende mærke «. ${ }^{14}$ I sin undersøgelse af attenhundredetallets kvindelige litteratur, har Catherine Gallagher for nylig hævdet, at romanernes "megen specificitet og særegenhed i form af realistisk gengivelse « hjalp med at danne middelklasse-subjektet som et økonomisk subjekt. Romanen hjalp ifølge Gallagher med at skabe ikke kun sympati, men sympatisk »appropriation « i læseren, ${ }^{15}$ en psykologisk og følelsesmæssig formåen, som blev »en af mange måder at lette ejendoms ombytning og investering i perioden, der skabte det spekulative, kommercielle og følsomme subjekt « ${ }^{16}{ }^{16}$ Gilbert og Gubar mener, at romanen ikke skaber et klassebaseret, men et socialt subjekt, der er kønsbaseret. De argumenterer for, at romanens fortællende struktur, særligt dens evne til at fortælle en historie fra en eller flere synsvinkler, fremmede en autoritativ 'uselviskhed', som var kompatibel med kvinder fra det nittende århundrede, som af en patriarkalsk kultur havde lært »at tale indirekte frem for direkte «, ${ }^{17}$ at konstruere deres egne identiteter, med andre ord, gennem realiseringen af anderledeshed.

Det er imidlertid ikke kun overbevisningen om romanens styrke til at 
fremkalde sympati, der forbinder disse litterater med en xldre tradition inden for romanteori. Det er også deres tendens til at henføre social virkeevne til formen såvel som til indholdet i romanerne. Denne tendens er måske mindst synlig hos Nancy Armstrong, som i sin fremstilling af det attende århundredes britiske fiktion argumenterer for, at romanens karakteristiske genretræk, dens repræsentation af karakteren som psykologisk kompleks, var en af mange sociale kræfter, som hjalp til med at skabe et karakteristisk 'moderne' subjekt. ${ }^{18}$ Alligevel er andre historistiske arbejder mere tvetydige i forhold til romanens status som en årsagsbestemt kraft. Når f.eks. D. A. Miller læser viktorianske romaners intrikate plotstrukturer som noget, der skaber et 'liberalt' socialt subjekt, eller når Philip Fisher præsenterer manglen på kompleksitet og tillid til kulturelle stereotyper i det nittende århundredes amerikanske sentimentale roman som noget, der skaber det 'radikale værk' af de-radikaliserende kulturforandring, skal vi så konkludere, at romanen er en social diskurs som ethvert andet værk? ${ }^{19}$ Eller, hvis vi skulle forstå romanen som usædvanlig magtfuld til at skabe den socialitet, som kommer til at definere en given periode, hvad skal vi så tro, gør romanen så usædvanlig andet end dens form?

Fristelsen til at betragte romanen som noget, der formmessigt skaber social forandring er mest tiltalende for de kulturhistorikere, som er blevet stærkt påvirket af marxismen. I sin nye introduktion til Marxist Literary Theory, opfatter Terry Eagleton ideen om en formideologi som nøglen til at undgå, på den ene side, »ren formalisme« og, på den anden side, »vulgær sociologi«: »Indsatsen her er, at det er muligt at finde den materielle historie, som skaber et kunstværk indskrevet i selve dets tekstur og struktur i form af dets sætninger eller i dets spil med narrative synsvinkler, i dets valg af et metrisk skema eller dets retoriske virkemidler «. ${ }^{20}$ Eagleton citerer på anerkendende vis værker af Walter Benjamin, Lucien Goldmann og Theodor Adorno for at være værker, der bidrager til udvikling af ideologisk form; og Raymond Williams med sin ide om en »følelsesstruktur « og Fredric Jameson med sin overbevisning om, at romaner synliggør en bestemt kulturs »mesterkode «, burde med sikkerhed inkluderes på hans liste, hvad enten vi ønsker at betegne Althusser som den mest indflydelsesrige social-teoretiker i denne tradition eller ej. ${ }^{21}$ Dog kan Eagleton og hans undervisere, som Catherine Gallagher har pointeret, kun fastholde kunstens traditionelle epistemologiske privilegium ved at tildele den en materiel autonomi frem for en ideologisk autonomi: »Williams og Eagleton fastholder det »idealistiske « fokus på kunstens ikke-reducerbarhed og autonomi, dens særlige æstetiske natur, men redefinerer denne autonomi som værende materiel i sig selv «.22 Gallaghers påstand stammer fra Pierre Macheray, der viser, hvordan en social værdi, som kausalt nedstammer 
fra udefrakommende faktorer, for litterære marxister kan falde sammen i et iboende træk i kunstværket: »At forklare værket er at vise, at modsat af hvordan det fremtræder, så er det ikke uafhængigt, men bærer i sin materielle substans aftrykket af et bestemt fravær, som også er dets identitetsprincip « ${ }^{23} \mathrm{I}$ hele handlingen, som går ud på at vise kunstværkets afhængighed af samfundet, finder Macheray frem til en ny kilde til kunstnerisk autonomi: kunstværkets materialitet indeholder i sig selv et 'aftryk', som gør dets sociale karakter både letlæselig og selvtilstrækkelig.

Vagheden hvormed Macheray behandler materialitet er en tvetydighed, som kan føres tilbage til Marx selv. I Kapitalen forklarer Marx aldrig tydeligt, hvordan »abstrakt menneskelig arbejdskraft er objektiveret [vergegenständlicht] eller materialiseret « i genstande. ${ }^{24}$ Han beskriver f.eks. arbejdskraft som værende »indkapslet « i en frakke eller som »koagulerende « i en objektiv form. ${ }^{25}$ Disse metaforers tvetydighed genlyder i Raymond Williams' forsøg på at definere den objektive betydning, som er indeholdt i et kunstværks materialitet: »Ethvert specifikt kunstværk er oplost i det, på hvert niveau af dets processer, ikke kun særlige sociale forhold, men også særlige materielle produktionsmidler, hvis beherskelse kunstværkets produktion afhænger af « (min fremhævning). ${ }^{26}$ Marxister, såsom Althusser, anerkender ved lejlighed, at ikke al materialitet er den samme: »Selvfølgelig har ideologiens materielle tilstedeværelse i et apparatur og dens praksisser ikke den samme modalitet som den materielle tilstedeværelse af en brosten eller en riffel «. ${ }^{27} \mathrm{Og}$ alligevel får Althussers helt særlige interesse for det materielle, der gør ideologi letlæselig, ham til hurtigt at overse alle forskellene, som han skaber: "Jeg skal på sin vis forlade problemet vedrørende en teori om forskellene mellem materialitetens modaliteter « ${ }^{28}$ Gallagher præciserer de teoretiske glidninger som en sådan laissez-faire holdning til forskellene mellem materielle 'modaliteter' skaber:

"Når så faste materielle genstande som sko og kartofler »læses « som tegn inden for komplekse betydningssystemer, bryder forskellen mellem materielle og symbolske produkter sammen. Den fysiske genstand bliver et tegn og de fysiske egenskaber for konventionelt anerkendte tegn ( $\mathrm{fx}$ de auditive og visuelle egenskaber for talte og skrevne ord) fremhæves. Alt kan så forekomme lige autonomt og afhængigt, bestemt og bestemmende, henvisende og selvhenvisende, symbolsk og virkeligt. «29

Det er min påstand, at det er denne glatte materialisme, som skaber en bro mellem marxistisk litteraturkritik og anglo-amerikansk litterær forma- 
lisme. Og for at demonstrere, hvordan romanteorien er blevet væsentlig $\mathrm{i}$ smedningen af denne forbindelse, har jeg koncentreret min studie af socialformalisme omkring to nøglefigurer: Henry James og M. M. Bakhtin. Selvom anglo-amerikanske litterater eksplicit vendte opmærksomheden mod Bakhtin i forsøget på at komme hinsides jamesisk formalisme, er det faktisk overensstemmelsen mellem Bakhtin og James, som, efter min mening, fik anglo-amerikanske teoretikere til at tage imod Bakhtin med en sådan begejstring. I stedet for at afvise James har nutidige romanteoretikere med andre ord blot raffineret James' grundlæggende genkarakterisering af romanen som en genre, der ikke kun repræsenterer identitet gennem dens indhold, men som en genre, der rent faktisk eksemplificeres gennem sin form.

Romanteoretikere var selvfølgelig ikke de første til at lovprise romanerne for deres evne til at repræsentere det sociale liv. Men før James, drejede diskussionerne om romanens sociale mimesis sig om indhold og karakterer. Romanforfattere og anmeldere diskuterede kvaliteten af autoritativ viden og moral i en roman, og hvordan romaner kunne påvirke social adfærd. ${ }^{30}$ Men ved århundredeskiftet skabte den tiltagende sidestilling af romanens realisme og romanens objektivitet en vis teoretisk forlegenhed omkring de romanforfattere, som skrev disse realistiske portrætter af samfundet. ${ }^{31}$ Hvordan kunne romanen tænkes at levere et objektivt billede af det sociale liv, når den kun var et produkt af en persons vision? Frem for at svigte projektet, som gik ud på at definere romanens realisme som den objektive repræsentation af samfundet, begyndte romanteoretikere at adressere problematikken vedrørende forfatterens subjektive partiskhed ved at betragte skønlitterær repræsentation som en social erfaring i sig selv. ${ }^{32}$

Hvad der umiddelbart adskilte James' og Lubbocks romanteori fra tidligere redegørelser for romanen, var den mærkelige abstrakthed med hvilken James og Lubbock behandlede det hidtil konventionelle syn, at romanen frem for alt skulle være en representation af samfundet. I de teorier, som skaber, hvad jeg kalder den socialformalistiske tradition, er socialitet i romanen ikke defineret som overbevisningerne, værdierne og måderne at opføre sig på, der tilhører en gruppe af karakterer, og den kan heller ikke lokaliseres i repræsentationen af bestemte politiske, retsmæssige, økonomiske eller kønsmæssige systemer, som påvirker karakterernes identiteter og handlinger. Det sociale er, ganske kort, knapt tematisk defineret, fordi ethvert tema så let vil kunne blive reduceret til en forfatters subjektive projicering. I stedet, ved snævert at karakterisere det sociale som den erfaringsmæssige interaktion mellem menneskelige subjekter, behandler sociale formalister denne relationalitet som romanens formelle 
ejendom. Den succesfulde romanforfatter er for disse teoretikere den virtuose, som både er villig og i stand til at maksimere romanens generiske disposition for at udtrykke social beslægtethed. Sådan en forfatter profiterer til gengæld ved at sikre en objektiv repræsentation af sin egen identitet, for så vidt som hun tillader romanens samfund og ikke sit eget påtrængende ego at repræsentere sig.

Ved den socialformalistiske traditions begyndelse prøver teoretikerne at bevise, at romaner eksemplificerer sociale relationer ved at fremlæse de altruistiske bånd, som de påstår, at romaner skaber mellem forfatter, fortæller, karakter og læser. I det senere tyvendeårhundredes teori vokser dette formelle syn på sociale relationer i stigende grad uafhængigt af selve romanen - måske ikke overraskende, eftersom det sociale i denne teoretiske tradition har så lidt at gøre med romanens indhold og begynder at optræde i redegørelser for narrativt sprog i almindelighed, i redegørelser for sprog i almindelighed, for samfundet i almindelighed og sidst, men ikke mindst, $i$ en omvending af denne traditions universaliserende bane, i redegørelser for underordnede sociale identiteter. Idet socialformalisme udvikler sig fra romanteori til socialteori bliver nogle af dens etiske implikationer genundersøgt. De tidligere, positive opfattelser af romanens sociale relationer som værende altruistiske bliver udfordret af en politisk kritik, der redefinerer altruisme som en maske for anvendelse af hegemonisk magt. Men hvad der er bevares fra romanteorien, er troen på, at formelle markører ikke kun kan udtrykke den egentlige sociale karakter af ens identitet, men også legemliggøre den.

Jeg påstår selvfølgelig ikke, at den socialformalistiske tradition, som jeg analyserer, er den eneste indflydelsesrige konceptualisering af romanen, som det tyvendeårhundrede har præsteret. Dog, som jeg håber at vise, bærer omfanget af traditionen og rækken af tænkere, den inkluderer, et vidnesbyrd om vigtigheden i og kraften bag socialformalisme som teoretisk logik. Det er bestemt ikke usædvanligt at placere de tænkere, som er i fokus i min undersøgelse - Henry James, Percy Lubbock, Wayne Booth, Gérard Genette, Roland Barthes, M. M. Bakhtin, Henry Louis Gates og Barbara Johnson - på det samme teoretiske kontinuum. Dog er dette kontinuum sædvanligvis beskrevet teleologisk: bevægelsen fra Henry James til Henry Louis Gates er kortlagt som en uafbrudt intellektuel udvikling fra kunstfærdig og formfuldendt formalisme til sofistikerede og yderst tekniske poststrukturalistiske opfattelser af sprog, litteratur, selv og samfund. Ved at afdække det socialformalistiske underplot inden for fremskridtsorienterede redegørelse for romanteoriens fremgang og tilbagegang, håber jeg at styrke vores forståelse ikke kun af, hvordan romanen er blevet teoretiseret i det tyvendeårhundrede, men også af, hvorfor en 
romanbaseret forståelse af social identitet har overlevet poetikkerne, som opfandt den.

[Redaktionens bemærkning: I originalen følger hér en gennemgang af de enkelte kapitler i Social Formalism, som vi har valgt at udelade.]

Så fra James til Johnson fastholder socialformalisten, at individuel identitet er radikalt dannet af dens interpersonelle relationer, og at denne relationelle subjektivitet kan objektiviseres i repræsentative former. En tradition, der begynder med definitionen på subjektiviteter som synsvinkler og kulminerer i definitionen af sprog som subjektiviteter, er baseret på det varige begær efter at forestille sig, at selv decentraliseret identitet kan have stabilitet, at både menneskers og litterære genrers 'karakterer' kan blive genkendt gennem deres materielle manifestationer i sprog. For formalister bliver romanens sociale arbejde i sagens natur kun overfladisk fuldendt af romanens skildring af fiktive karakterer. Romanens dybere sociale magt ligger i dens evne til at objektivere synsvinkler.

Teoretikerne, som jeg har valgt at analysere i Social Formalism, anskues både som representanter for og som store skabere af den socialformalistiske tradition. Min hensigt har ikke været at bygge et familietræ for romanteorien, der vil kunne katalogisere alle dens tendenser og kortlægge deres indre relationer. Det har heller ikke været at redegøre udtømmende for en tradition, som jeg ser som værende dybtgående, rig og kompleks. Jeg har efterstræbt at tage en eksemplarisk, snarere end en udtømmende, liste af teoretikere i øjemål for at vurdere en særlig teoretisk traditions logik og desuden også for at forklare, hvordan denne logik har fået andel i nutidig teori. Min målsætning har været at identificere en sådan tradition, at have dokumenteret dens overraskende rækkevidde og indflydelse, at have klarlagt dens logik og at have evalueret både præmisserne og konsekvenserne af denne logik.

Ved at genskrive historien om romanteorien håber jeg, at det er lykkes mig at motivere undersøgelsen af større filosofiske emner, som med fordel kan føre til afklaring af teoretiske formodninger om romanen, der rækker ud over de skarpe grænser for den socialformalistiske tradition. Hvor seriøst skulle vi f.eks. tage antagelsen om, at romanen som genre i særlig grad er i stand til at repræsentere anderledeshed? Og hvor megen moral såvel som æstetisk tyngde ønsker vi at tildele en romanforfatters evne til at representere anderledeshed? Giver det overhovedet mening at tænke på en romans karakterer som noget, en forfatter kan frigøre eller undertrykke? Hvis disse spørgsmål lyder mærkeligt gammeldags, kan det være fordi de ikke er blevet passende stillet af nutidig teori. Eller det kan være, at vi - på trods af de sandheder, som vi tror, vi har lært fra poststrukturalistisk teori - stadig tror på de etiske imperativer, som gjorde 
socialformalismen så vedvarende overhovedet. Det første skridt i retning af at isolere disse imperativer og definere den teoretiske tradition, som de har inspireret, er genvurderingen af romanteorien, og det er, hvad jeg har forsøgt her. Jagten på svar på disse spørgsmål er en opgave for fremtidige teoretikere, som enten vil forsvare eller tilbagekalde romanens status som den mest sociale af de litterære former.

Oversat af Anja Pedersen, redigeret af Per Krogh Hansen, efter Social Formalism. The Novel in Theory from Henry James to the Present by Dorothy Hale, copyright 1998 ved the Board of Trustees of the Leland Stanford Jr. University. Oversat efter aftale med Stanford University Press, www. sup.org.

\section{Noter}

1 I 1952 påstod John Aldridge, at en poetik for romanen var umiddelbart forestående: »Vi har endnu ikke formuleret den, kodificeret dens indsigter eller værdiget den en term, hvilket vi bestemt skal og allerede har gjort i kritikken af lyrikken". John W. Aldridge (ed.): Critiques and Essays on Modern Fiction, 1920-I 951, New York 1951, p. iv. Men så sent som i 1961 kunne Robert Scholes præsentere en samling essays om romanen ved at erklære, at »indtil nu, er der ikke blevet skrevet et værk, som vi kan pege på som en poetik for romanen«. Robert Scholes (ed.): Approaches to the Novel. Materials for a Poetics, San Francisco 1961, p. v. I 1967 var romanstudiet rigt nok til at have sit eget tidsskrift, Novel, og 1984-udgaverne heraf kan anskues som et vandskel i romanteoriens flod og ebbe. Helliget spørgsmålet: »hvorfor spiller romanen en rolle", afspejlede denne række af numre de skiftende kriterier for kunstnerisk merit. Den litterære status, som utrolig mange teoretikere og litterater søgte at skænke romanen, var pludselig et ansvar; jo mindre litterært et kunstværk var, jo mere 'ægte' kunne det være. I deres introduktion til en essaysamling lavet på baggrund af udgivelsesserien, spørger redaktørerne på Novel: »Hvorfor spiller romaner, når alt kommer til alt, en rolle i en tid, hvor litteraturkritikken synes at beskytte os mod litterære fiktioner ved at udstille deres vovede sociale koder eller omvendt ved at bekræfte dem på forskellige måder i 'sprogets fængselsbygning'? « Mark Spilka et. al. (ed): Why the Novel Matters: A Postmodern Perplex, Bloomington 1990, p. 198.

2 Gerald Prince: »On Narrative Studies and Narrative Genres «, in Poetics Today II (1990), p. 271. Mens sådanne debatter er allestedsnærværende, leverer nummer 2 og 4 af Poetics Today (1990) en vigtig vurdering af narratologien af grundlæggere og praktikere på området. Se Seymour Chatman: Coming to Terms: The Rhetoric of Narrative in Fiction and Film, Ithaca 1990, for den narratologiske debat vedrørende 'implicitte' agenters status samt et forsvar for den implicitte forfatter.

Man kunne sammenligne den terminologiske knopskydning, som Prince citerer som et af narratologiens hovedbidrag, med redegørelsen for »narrativ procedure « i Bleak House, som vist af D. A. Miller. Millers fremragende læs- 
ning af »formen « på Bleak House er, som jeg senere vil vise, uadskillelig fra en forståelse af romanens generiske identitet. Alligevel har hans diskussion af plottets funktion, karakteriseringens funktion, narrationens funktion og beskrivelsens funktion mere brug for de tekniske begreber, der er leveret af Foucaults opfattelse af den sociale magts funktion end for det specialiserede narratologiske vokabular. Se D.A. Miller: The Novel and the Police, Berkeley 1988, pp. 58-106. For en glimrende kort oversigt over narratologien, se Claudia J. Brodsky: The Imposition of Form: Studies in Narrative Representation and Knowledge, Princeton 1987, pp. 3-16.

3 Feministerne var blandt de første til at forestille sig, at ideologi var en udfordring for den narratologiske disciplin. Så tidligt som i 1981 kritiserede Susan Sniader Lanser narratologiske synsvinkelteorier for at forsøge at være "værdifri«. Se Susan Sniader Lanser: The Narrative Act: Point of View in Prose Fiction, Princeton 1981, p. 42. På det seneste, i hendes »Shifting the Paradigm: Feminism and Narratology«, in Style 22 (1988), pp. 52-60, og i »Toward a Feminist Narratology«, in Robyn R. Warhol et. al. (ed): Feminism: An Anthology of Literary Theory and Criticism, New Brunswick, N.J. 1991, pp. 610-29, generaliserer Lanser det feministisk, politiske »formål «, som en øvelse i et kritisk syn muliggjort af kvindens identitet som et socialt subjekt, især den mandlige hegemonis undertrykkelse af hende. I sammenligning med videnskabsmanden, som arbejder på at skabe objektive undersøgelsessmodeller, forfølger feminister ifølge Lanser i stedet et politisk mål, et mål, der, som hun formulerer det, er en synsvinkel i sig selv: kvinders sociale vilkår i form af »udenforståenhed « udmærker dem til at »levere et perspektiv udefra på alle intellektuelle undersøgelsesområder «. Lanser: "Shifting the Paradigm «, p. 54. Robyn Warhols udgave af en feministisk narratologi forsøger sig med en revisionistisk læsning af både den ideologiske betydning af det nittende århundredes narrative teknik og »kønsfordommene i litterære teorier, der har overset den engagerede fortæller som en konvention, der er central for realistisk fiktion". Robyn R. Warhol: Gendered Interventions: Narrative Discourse in the Victorian Novel, New Brunswick, N.J. 1989, p. 24.

Skiftet fra formelle studier af romanen til studier af romanen som ideologi kan ses mere generelt hos de amerikanske litterater, som i 1980'erne begyndte at udforske problemstillinger forbundet med romanens narrative form, og som afsluttede årtiet med at betragte romanen som en kulturel diskurs. Hos James Phelan, for eksempel, efterfølges Worlds from Words: A Theory of Language in Fiction, Chicago 1981 af Reading Narrative: Form, Ethics, Ideology, Columbus 1989. D. A. Millers Narrative and Its Discontents: Problems of Closure in the Traditional Novel, Princeton 1981 bliver efterfulgt af The Novel and the Police (se note 2).

For en optimistisk redegørelse for, hvordan narratologi ikke nødvendigvis skal erstattes af, men snarere må møde og fortsætte ideologisk fortolkning se: Elizabeth Wright: "An Ideological Reading of Narrative «, in Poetics Today 11 (1990), pp. 437-42, en 1990er-anmeldelse af mangfoldige nyere tendenser i narrativ teori. Se Prince: »On Narratology (Past, Present, Future) «, in Hardee Maynor et. al. (eds): Narratology and Narrative, Columbia, S.C 1990, pp. 1-14, for en mere udfoldet redegørelse for udfordringerne stillet til narratologien af ideologiske litterater. Prince udpeger Jean-Michel Adams og Marie-Laure Ryans studier, ligesom han også fremhæver Lanser og Warhol. 
Se også hans seneste debat med Lanser: Gerald Prince: »On Narratology: Criteria, Corpus, Context«, in Narrative 3 (1995), pp. 73-84 og Susan Sniader Lanser: »Sexing the Narrative: Propriety, desire, and the Engendering of Narratology«, in Narrative 3 (1995), pp. 85-94.

4 Wallace Martin, for eksempel, optegner i sit overblik over narrativ teori holdningerne, der korrelerer romanens status som den mindst 'kunstneriske' af alle genrer med dens evne til at levere »en optegnelse over problemerne, der konfrontere individer i en stabil social struktur på grundlag af deres omstændigheder og klasseoprindelse, eller de problemer de står overfor, når de bliver konfronteret med social forandring «. Wallace Martin: Recent Theories of Narrative, Ithaca 1986, p. 18.

5 Eve Kosofsky Sedgwick: Between Men: English Literature and Male Homosocial Desire, New York 1985, p. 5 (herefter forkortet $B M$ ).

6 Sedgwick fortolker amerikansk ideologi og kultur så bredt, at hun med fuldt overlæg vælger at behandle romanen og filmversionen af Gone with the Wind som udskiftelige kulturelle artefakter.

7 Sedgwicks forståelse af romaner som »ideologiske mikrokosmosser « retfærdiggør for hende ikke kun undersøgelsen af litteratur i sig selv, men også analysemetoder, som moderne literater har anvendt på litteratur - i særdeleshed den nykritiske nærlæsningspraksis. Hvis en hel ideologisk diskurs kan presses ned i en roman som Gone with the Wind, kan det, der står med småt, kun tydes gennem et særdeles detaljeret engagement med det litterære værks repræsentationsstrategier: »Det er af stor politisk betydning, at vores redskaber til at undersøge den betydningsdannende relation er hårfine og fintmærkende«. $B M$ p. 10. Jf. Carolyn Porters kritik af nyhistoricismen, hvori hun argumenterer for, at den »sociale tekst ender med at blive læst, som vi er blevet skolet til at læse en litterær tekst, og det er ud fra traditionelle formalistiske termer «. Carolyn Porter: »History and Literature: 'After the New Historicism' ", in New Literary History 21 (1990), p. 257.

8 Se Percy Lubbock: The Craft of Fiction, New York 1931, p. 251; Jane P. Tompkins: Sensational Designs: The Cultural Work of American Fiction, 1790-1860, New York 1985, p. xiii.

9 Sedgwick er afgjort mindre bekymret end Tompkins for formidlingen af fortidig ideologi med en nutidig synsvinkel. Hun indrømmer ærligt, at hun har både »historiserende og dehistoriserende hensigter«: »Som kvinde og som feminist, der (til dels) skriver om mandlig homoseksualitet, føler jeg, at jeg må være særlig eksplicit om de politiske grundlag, antagelser og ambitioner for dette studie, også i den henseende. Min hensigt har hele vejen igennem været at foretage en antihomofobisk såvel som en feministisk undersøgelse«. $B M$, p. 16, 19. Men det viser sig, at dehistorisering og historisering alligevel er bemærkelsesværdigt forenelige beskæftigelser. De politiske værdier, som Sedgwick besidder, er helt forenelige med det historiebillede, hun leverer. Det litterære mikokosmos' selvtilstrækkelighed synes at give Sedgwick både et holdepunkt for fortidig ideologi og den ydre standard til at måle nutidig ideologi med, som hun behøver.

Paul Ricoeurs karakteristik af Althusser gør det klart, hvordan den marxistiske tro på videnskabelig objektivitet også hjælper med at fordrive bekymringen om ideologisk formidling: »[Althussers] påstand er, at mens ingen marxist kan sige noget som ikke er ideologisk, vedrørende forvrængningens rødder i 
nogle mere fiktive lag, vil han eller hun måske stadig tale videnskabeligt om det ideologiske apparat, inden for hvilket forvrængningen foregår « Paul Ricoeur: »Althusser's Theory of Ideology«, in Gregory Elliott (ed.): Althusser. A Critical Reader, Oxford 1994, p. 62. Men selvom Sedgwick implicit må være i gæld til en sådan større marxistisk metodologisk trøst, er dette særlige argument ikke et, som hun direkte påkalder. Det virker som om, hun ønsker at finde objektivitet i selve den litterære form.

Det er interessant at bemærke, at Jonathan Arac, ligesom Sedgwick, definerer problemet med nutidig ideologi med udtryk fra samtidig politik. Men han er mere pessimistisk i forhold til den politik, der er tilgængelig for akademikere: "Som kultur-intellektuelle deltager vi i en hegemonisk praksis, mere end vi nogensinde kan vide fuldt ud, alligevel forstår vi også os selv i vores aktiviteter som lærere, forskere og forfattere som nogen, der udfører 'modarbejde', som ikke kun forsøger, men til en vis grad lykkes med at lave en åbning, hvor alternative syn og praksisser kan tænkes at dukke op«. Jonathan Arac: »Rhetoric and Realism; or Marxism, Deconstruction, and the Novel «, in Joseph A. Buttigieg (ed.): Criticism Without Boundaries: Directions and Crosscurrents in Postmodern Critical Theory, Notre Dame 1987, p. 174.

10 Tompkins: Sensational Designs, p. xiii. Ruth Bernard Yeazell deler Sedgwicks og Tompkins tro på, at historisk nøjagtighed ikke behøver at blive kompromitteret af den nødvendige projektion af den nutidige kulturelle identitet på fortiden. Yeazell hævder, at den forståelse af kultur, som kommer til udtryk i essayene i hendes antologi, er tidligere forståelser overlegen, fordi analysen er mere inklusiv - og derfor antageligt mere nøjagtig - og alligevel hævder hun også, at nøjagtighed er irrelevant, eftersom enhver nutidig kritisk enstemmighed ikke udtrykker en objektiv sandhed om fortiden, men den objektive sandhed i nutidigt begær: »Ved ikke at ville isolere skreven fiktion fra andre representationsformer, bidrager forfatterne til en analyse, ikke kun af det nittendeårhundredes romaner, men af kulturen som et hele. Hele konvergensen af deres argumenter i en tvingende diagnose af det nittendeårhundredes angst, ja selv deres succes med at identificere sådan en angst, kunne imidlertid give os anledning til at spørge til, hvilke af vores egne ængstelser denne nye læsevane søger at styre og kontrollere«. Ruth Bernard Yeazell (ed.): Sex, Politics, and Science in the Nineteenth-Century Novel, Baltimore 1986, p. xii.

11 Tompkins »sympati« synes derfor at være den poststrukturalistiske udgave af romanens "forestillingsevne «, som den blev lovprist af Brooks og Warren i deres Understanding Fiction: »Hele denne tekstbog er helliget resultaterne (og de lejlighedsvise fejltagelser) af fiktionsforfatterens forestillingsevne, eftersom han forsøger at presentere sandheden om menneskelivet «. Cleanth Brooks and Robert Penn: Understanding Fiction, 3rd ed. Englewood Cliffs 1979, p. 514. Bemærk også overensstemmelsen mellem de første Tompkins steder om kulturel fremmedhed og Van Ghents humanistiske påstand om, at romaner »udvider vores liv i vidde og forskellighed «. Dorothy Van Ghent: The English Novel: Form and Function (1953), New York 1961, p. 7.

David Minters undersøgelse af den amerikanske roman antager på lige vis værdien af anderledeshed som et generisk imperativ: »Ved at lære os, hvordan sprog og kultur fungerer, løfter romanerne os ind i smukke dagligstuer og ned i de elendige by-slumkvarterer [...] De giver os en fornemmelse af, hvordan tilværelser levet på andre tider og steder var forskellige fra vores eget liv. De 
udfordrer os til at registrere stemmer, hvis moral og kulturelle genlyde - eller kønsmæssige og racemæssige genlyde - er forskellige fra vores egne«. David Minter: A Cultural History of the American Novel: Henry James to William Faulkner, New York 1994, pp. xv-xvi.

12 Der er sådan en mangfoldighed af fremragende socialhistoriske undersøgelser af romanen, at det virker uhensigtsmæssigt at fremhæve en enkelt som paradigmatisk, men Michael Gilmores »The Book Marketplace I «, in Emory Elliott (ed.): The Columbia History of the American Novel, New York 1991, pp. 46-71, fungerer afgjort som et eksempel på den slags socialstudie, som diskuterer romanens form uden at tingsliggøre den.

13 Bayms studie dokumenterer at førborgerkrigskulturens teoretisering af romanen var socialt subversiv: »Ved at tilfredsstille selvet frembringer romaner selvkærlighed og en tendens til selvhævdelse, som gør sindet uregerligt og derfor bringer agenterne for social og psykologisk kontrol i fare « Nina Baym: Novels, Readers, and Reviewers: Responses to Fiction in Antebellum America, Ithaca 1984, p. 39. Selvom hendes undersøgelse er interesseret i den historiske definition på romanens generiske magt, synes Baym nogle gange at argumentere ahistorisk for »formens iboende kraft til at skabe spænding for læseren «. Op.cit., p. 43.

Cathy N. Davidson fremfører også den position, at romanen udgjorde en fare for førborgerkrigskulturen. Davidson synes også at mene, at romanens evne til at skabe social omvæltning ikke kun er specifik historisk, men generisk iboende: »Læseren er 'tilstede under samtalen' og bliver imaginært del af selskabet. Hvad enten læseren er en højagtet politisk leder eller en lavtstående trykkers lærling, er han/hun privilegeret i forhold til teksten, han/hun bydes velkommen ind i teksten, og bliver, på en måde, til teksten."

14 Richard H. Brodhead: Cultures of Letters: Scenes of Reading and Writing in Nineteenth-Century America, Chicago 1993, pp. 17-19.

15 Cathrine Gallagher: Nobody's Story: The Vanishing Acts of Women Writers in the Marketplace, 1670-1820, Berkeley 1994, p. 173.

16 Op.cit., p. 194.

17 Sandra M.Gilbert and Susan Gubar: The Madwoman in the Attic: The Woman Writer and the Nineteenth-Century Literary Imagination, New Haven 1979, p. 548.

18 Nancy Armstrong: Desire and Domestic fiction: A Political History of the Novel, New York 1987, pp. 3-8.

19 For hele Millers erklæring vedrørende den sociale agens af romanens henholdsvis formelle, tematiske og markedsmæssige værdier, se The Novel and the Police, p.x (se note 2). For Millers særlige diskussion af den kulturelle funktion af den viktorianske romans formelle kompleksitet, se især pp. 81-106.

Philip Fisher hævder på lignende vis, at de formulariske plots og stereotype karakterer i det nittendeårhundredes amerikanske roman tilskyndede det »radikale 'arbejde' « i at fremme kulturel forandring. Ifølge Fisher tillod den læselighed, som gjorde romanen populær, også romanen at iscenesætte en "psykologisk prøve", som skaber en ordnet resignation, der lader en gruppe »indse'..., [hvad] de allerede har valgt og sat i bevægelse, men som ikke moralsk eller psykologisk har sat sig igennem endnu", Philip Fisher: Hard Facts: Setting and Form in the American Novel, New York 1985, pp. 18-19.

20 Terry Eagleton et.al. (ed.): Marxist Literary Theory, Oxford 1996, p. 11. 
21 Ligesom Eagleton forsvarer Jameson udtrykkeligt ideen om »formens ideologi«, in Fredric Jameson: The Political Unconscious: Narrative as a Socially Symbolic Act, Ithaca 1981, p. 76. Jamesons egen Percy Lubbock, William C. Dowling, laver indirekte forbindelsen mellem poststrukturalistiske opfattelser af romanen og den jamesiske tradition, når han erklærer at: »Problemet, som er taget op af Grammatology og The Political Unconscious [...] er problemet omkring stil som lovhåndhævelse: en måde at skrive på, som både viser og forteller, hvad den prøver at få igennem«(Op.cit., p. 11; Dowlings fremhævelse). Brodsky bekræfter Jamesons fornemmelse af, at »fortællingen er den litterære form, som i bredeste forstand forstås som skabende sin egen logiske forståelse«. Brodsky, p. 3 (se note 2). For Lucien Goldmann er forbindelsen mellem romanens form og samfundet mindre et mikrokosmos end en ideologisk homologi, men romanformens forrang som afdækkende den sociale mening i teksten hersker der ikke nogen tvivl om: »Det første problem, som en sociologi om romanen skulle have konfronteret, er det om forholdet mellem romanformen i sig selv og det sociale miljøs struktur, i hvilken den blev udviklet $[\ldots]$ « Lucien Goldmann: »Introduction to the problems of Sociology of the Novel «, in Eagleton et. al. (ed): Marxist Literary Theory, p. 209; Goldmanns fremhævelse.

22 Catherine Gallagher: »The New Materialism in Marxist Aesthetics «, in Theory and Society: Renewal and Critique in Social Theory 9 (1980), p. 643. Se Francis Mulhern: "Althusser in Literary Studies«, in Elliott (ed.): Althusser, pp. 163-64, for en kritik af Eagleton, som er sammenlignelig med Gallaghers - en kritik, som han udvider til at omfatte Althusser og Macheray. Som andre litterater har bemærket, så er det overordnede problem med ideologisk autonomi et teoretisk kerneproblem i marxistisk teori: »Viden om sociale formationer er opnået ved at jonglere teoretisk med 'relativ autonomi' og 'determination i sidste instans' snarere end gennem empirisk og historisk forskning «. Kevin McDonnel og Kevin Robins: »Marxist Cultural Theory«, in Simon Clarke et al. (ed.): One Dimensional Marxism: Althusser and the Politics of Culture, New York 1980, pp. 160-61.

E. P. Thompson er selvfølgelig skarp i sin kritik af, hvad han betragter som Althussers afvisning af, hvad vi kunne kalde 'grundlæggende' værdier for superstrukturel kompleksitet. Han påstår, at Althussers strukturalisme får ham til at »være stille (eller undvigende), hvad angår vigtige kategorier, deriblandt 'økonomi' og 'behov'«. E. P. Thompson: The Poverty of Theory and Other Essays, New York 1978, p. 5.

23 Pierre Macherey: A Theory of Literary Production (1966). Oversat af. Geoffrey Wall. Boston 1978, pp. 79-80.

24 Karl Marx: Capital: Volume One, 1867. Oversat af Ben Fowkes, New York 1976, p. 129.

25 Op.cit., p. 142.

26 Raymond Williams: Marxism and Literature, New York 1977, p. 163. Se Simpson for en skarp kritik af den exceptionelle definition på kunst, der er antydet i Williams' begreb om »følelsens struktur«. David Simpson: »Feeling for Structures, Voicing 'History'", in Christopher Prendergast (ed.): Cultural Materialism. On Raymond Williams, Minneapolis 1995, pp. 38-39, p. 44 f.

27 Louis Althusser: »Ideology and Ideological Apparatuses (Notes Toward an Investigation)«, in Ben Brewster (ed.): Lenin and Philosophy, London 1971, 
p. 156.

28 Raymond Williams: Problems in Materialism and Culture, London 1980, p. 159. Modsat forsøger Williams at foretage en sortering af de forskellige typer af materialitet, som skulle angå en materialist. Men i Marxism er hans historiske redegørelse for måden, hvorpå samfundet har anset kunst for at være materiel, i konflikt med hans egen teoretiske opfattelse af kunstens materialitet. Raymond Williams: Marxism and Literature, New York 1977, pp. 159-62. Projektet med at vise, at forskellige kulturer behandler kunst som mere eller mindre materiel, fremmer ikke nødvendigvis projektet med at sige, hvorfor kunstværkets materialitet bør forstås i (post)marxistiske termer. Ofte sætter han i sin teoretiseren sin lid til, hvad vi måtte kalde en minimalistisk definition på kunstværkets materialitet ved enten at påkalde de »biologiske processer, især dem, som relaterer sig til kropsbevægelser og til stemmen, som ikke kun er grundlaget, men til tider er værkets mest kraftfulde bestanddele « (Problems, p. 113) eller også, mere specifikt for litterære kunstværker, »materielle noteringer på papir« (Marxism, p. 162). Mens få ville nægte, at det giver mening at tænke på kunst som materiel på denne elementære måde, forbliver det uklart, hvorfor f.eks. "noteringer« skulle blive anskuet som »legemliggørende mange af de mest intense og væsentligste former for menneskelig erfaring «: hvordan, med andre ord, litterære teksters status som genstande tillader os at læse dem som »særlige objektiviseringer« af social erfaring. Marxism, p. 162; min fremhævelse.

29 Gallagher: »The New Materialism«, p. 635 (se note 22).

30 Se Watt, hvis studie af det attende århundredes roman forbinder romanens generiske særegenhed med »individualiseringen af dens karakterer og med den detaljerede presentation af deres miljø«. Ian Watt: The Rise of the Novel, Berkeley 1957, p. 18.

31 Se Erich Auerbach: Mimesis: The Representation of Reality in Western Literature. Oversat af Willard R. Trask. Princeton 1953, pp. 534-38, for en diskussion af udviklingen af moderne skepsis over for »forfatteren som fortxller af objektive kendsgerninger« (op.cit. p. 534).

Det nittendeårhundredes forestilling om, at romanens realisme leverer et objektivt billede af livet, er glimrende kritiseret af Sartre: »Realismens fejl har været at tro, at det virkelige afslører sig selv til beskuen, og at man som følge heraf kunne tegne et uhildet billede af det. Hvordan skulle det være muligt, når selve perceptionen er partisk, idet navngivningen i sig selv allerede er en modificering af genstanden? «, Jean-Paul Sartre: »Why Write? «, in » What Is Literature? « and Other Essays, Cambridge, Mass. 1988, p. 66.

32 Filosoffen Martha Nussbaum tilbyder en humanistisk udgave af romanens strukturelle mulighed for at representere social identitet: »For mens de taler konkret om mennesker i deres forskellige sociale kontekster og ser den sociale kontekst i hvert tilfælde som relevant for valg, har de også, i hele deres struktur, indbygget en fornemmelse for vores frlles humanitet «, in Martha C. Nussbaum: Love's Knowledge: Essays on Philosophy and Literature, New York 1990 , p. 96. 